\title{
Towards Community Development: the Imperatives for Public Facilities Provision in Ilorin East, Nigeria
}

\author{
Akindele O. Akin \\ Urban and Regional Planning Department \\ LadokeAkintola University of Technology, Ogbomoso, Nigeria \\ oaakindele37@lautech.edu.ng \\ +2348038093456
}

\section{Abstract}

Communities have experienced stagnancy and even retrogression in terms of population flight, physical and socio-economic developments. Against this background, the study assessed the adequacy of public facility provision as well as community development in Ilorin East local government.Relevant data was obtained to investigate social economic characteristics, provision of public facility and the level of development; using a semi-structured questionnaire administered on 372 respondents across the 12 wards using a random systematic style.Likert scaling was done. Chi-square was used to explain the variation in the levels of facility provision as well as the level of community development among the wards. Linear regression analysis was used to explain the relationship between facility adequacy and community development. Generally low level of both facility provision and community development was observed in the study. There was also found a high and reliable positive correlation $(\mathrm{R}=.949)$ between public facilities and community development. The study thus recommendsan aggressive provision and maintenance of public facilities with emphasis on public-private cooperation. This is believed to be capable of producing a sustainable community.

Keywords: public facility, community development, public-private partnership, sustainability, Nigeria. 


\section{Introduction}

Facilities are provided to satisfy specific individual or community needs, including safety and security, communication, recreation, sport, education, health, public administration, religious, cultural and social (Fakere and Ayeni, 2013).Adequate provision of well-maintained and equitably distributed basic facilities is a prerequisite to economic vitality, human livability and sustainable environment; as it lowers production costs, raises the standard of productivity, employment and living. (Fakere andAyeni, 2013; McNeil, 1993). Efficient provision of basic facility is therefore both a perquisite to city liveability and a panacea to urban poverty.

Facilities in cities, due to incremental urbanization; increased demand for urban services, unsustainable use of resources, income inadequacies have been found inadequate(Olotuah and Adesiji 2005, Akinbamijo and Fasakin 2006, Essienet al 2012). The general absence of the basic necessities of man, such as good roads, water, medical services and a conducive living environment classifies Nigeria among poor countries of the world. This has emanated from the fallout or inadequate infrastructure, poor planning and management as well as alters neglect and poor integrated planning. (Essienet al, 2012, Owoeye 2012). The failure of basic facilities which otherwise should have been an added advantage of healthy urban growth, resulted in slow development and low standard of living which have posed dangers to the environment and human life.(Akinbamijo, 2006).

The deplorable state of Nigeria public facility begs serious attention and has for long remained an issue of public and political debates. Successive governments have always sought to expand the scope and range of public facilities provided especially in the urban areas (Adeboyejo and Abolade, 2007). Accessibility to good roads, hospitals, schools, markets recreational facilities and a pleasant environment is getting worse day in day out. The problem of facilities is visible in most Nigerian cities. This has been blamed on poor or the absence of scientific physical planning; privatization and commercialization of public facilities and services, the scarcity or dearth of these life sustaining facilities, and the care free attitude on the part of the government. Shifting a major part of the responsibility of basic facility provision have encouraged financial exploitation of residents and have impeded community development in a lot of ways.

Much more remains to be learnt:What are the available public facilities in the study area? What is the level of development in the study area? What is the relationship between public facilities and development in the study area? What are the major factors hindering the maintenance and adequacy of public facilities in the study area. To this end, this study assesses public facility provision in Ilorin East and how it 
implicates community development of the city. This is with the view to make relevant suggestions towards the creation of a better sustainable city development.

\section{Research Methodology}

Primary and secondary data were used. While maps and population data were obtained from secondary sources, the bulk of the primary data was obtained through the administration of a structured questionnaire administered to 273 respondents, using a multi-stage sampling procedure. The sample size represents $0.01 \%$ of the total $(273,189)$ population across the 12 political wards of the city. Likhert's scaling method was used to weigh the ordinal ratings to make the findings amenable to parametric testing. Correlation analysis was used to explain the relationship between facility adequacy and community development while t-test was used to explain the variance between the acceptable level of facility provision and the observed.

\section{Issues on Facility and Community Development}

Public facilities, infrastructural facilities, social services, social amenities and other similar terms have been interchangeably used. The World Development Report (1994) described infrastructures by given example of types: power, telecommunication, water, sewage, sewerage and so on. However, infrastructural facilities have been seen as life supporting facilities of which financial cost-benefit rationalization is not a principal objective(Igbozurike, 1998). He classified infrastructural facilities using the line of their functions into: advisory and institutional, composite and physical cum structural facilities. Obateru (2003) categorized it into physical and social infrastructures. The ultimate goal of infrastructure policy is to provide the necessary services of high quality and efficiency at low price to the ultimate users in the country (World Bank, 1994).

Development is a multivariate, quantitative and qualitative phenomenon which spans a very wide range of human endeavor compositing physical, social, economic, health, knowledge, technology and political visible advancements. While development has been described as a process by which one's overall personality and community is enhanced. (Smith 2000); facilities have been conceived asthe physical component of interrelated systems providing commodities and services essentially to enable, sustain or enhance societal living condition; they are necessary for an economy to function and they should be put in place to enable development to occur (Steven, 2003; Hirschman, 1958). Inadequacies of infrastructure and basic service cause poor health condition, reduction of the opportunities and degraded settlement environment (Ibrahim and Hadary, 2010). This is why the development of collective personality requires physical, material, and economic development (Okuneyeet al, 1990). 
Spatial efficiency, equity and equality; are all components of facility provision adequacy. Accessibility maximization in terms of minimized physical distance, number of consumers to which a unit of facility is dedicated, the standard of space required for convenience and functionality and maintenance all enter into facility provision adequacy. This is supported by the central place (Christaller, 1933) and location theories. Hierarchical clusters and densities can govern the location, quantity and quality of what facilities to be provided putting the concepts of threshold and range into consideration. This guarantees the avoidance of wastefulness that arises from over-serving and underserving parts of the community, thus allocation of resources to city parts becomes frugal. Policy formulation becomes easier and practicable. This is essential to solving specific social problems and promoting equity and social justice in an area The organization of any spatial unit is a function of equity and efficiency (Ibikunle, 1997).Facilities efficiency is indispensable to national economy. The market principle emphasizes that the most convenient, easiest, quickest and cheaper access to the goods and services is required by the consumer to contribute effectively to urban growth (Ukwu, 2001). The provision of these public facilities improves and greatly affects the quality of life and well-being of individuals within a given society which in turn influences social development.

The importance of public facilities is fetched in economic, social and political considerations (Garfield and Lovejoy, 1964 and Ugwu, 1993). Economically, public facilities are among basic industries on which national productivity depends and which absorbs large capital expenditures. Socially, public facilities are of great importance to transport communication, health, safety and other; in shaping life of people. Politically, they are the efforts and challenges faced by private bodies and enterprise that provides public services with the sole aim of making profit. The degree of comfort ability of people in any society is a function of the standard of living enjoyed by all which can be measured by the availability or incidence of basic facilities, utilities and service in that society (Ugwu, 1993).The pace of social and economic development of a country is to a large extent determined by facility adequacy and effectiveness, providing indispensable support for the expansion of production capacities facilitates both internal and external trade, increasing standard of living in terms of high per capita income, efficient health and social service delivery system. Efficient infrastructure are essential component in the effective functioning of cities which will contribute to economic development and poverty reduction via: Direct positive contribution to the growth in GDP; Positive multiplier effect in the other productive sectors of the economy and the facilitation due to economies of scale (Ogunjobi, 2003). 
Efficient facility provision suppresses production costs,influence the level of output, production diversification, trade expansion, employment, welfare and profitability(MC Neil, 1993). Rio Conference on environment and development (UN, 1992) recognized the importance of infrastructure in maintaining higher environmental standards. The conference posits that infrastructure has an impact on physical and socio-cultural aspects and has strong links with environmental sustainability.

\section{The Study Area}

Ilorin East which is cited at oke-oyi is sixteen kilometers from Ilorin, the kwara state capital. It lies on latitude $85^{\prime} \mathrm{N}$ and longitude $43^{\prime} \mathrm{E}$. The local government is transitional zone between the Northern and Southern part of Nigeria. This central location gives it a relatively easy accessibility from all parts of the country it shares boundaries with, Ilorin south local government, Ilorin west local government, Moro local government and Ifelodun local government.

Ilorin the capital of Kwara state is the economic and commercial nerve centre of the state. Economic activities include farming, trading, manufacturer, Baking and other tertiary activities. The farming activity involves such crops as groundnuts, maize, beans and vegetables. Tourists attraction in the area are the Dada pottery, Okuta Ilorin and Apado tunnel.

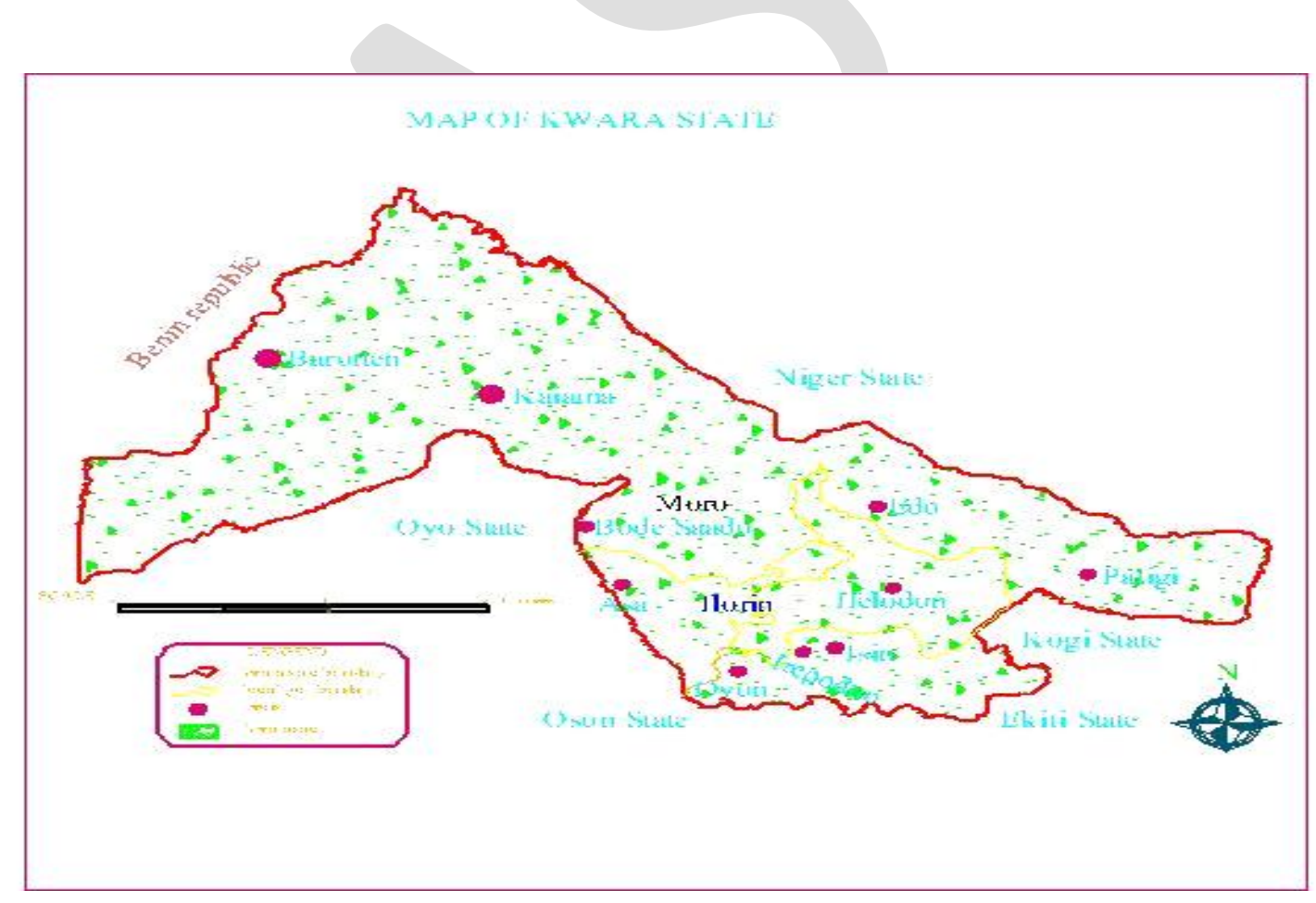

Figure 1: Map of Kwarastate 


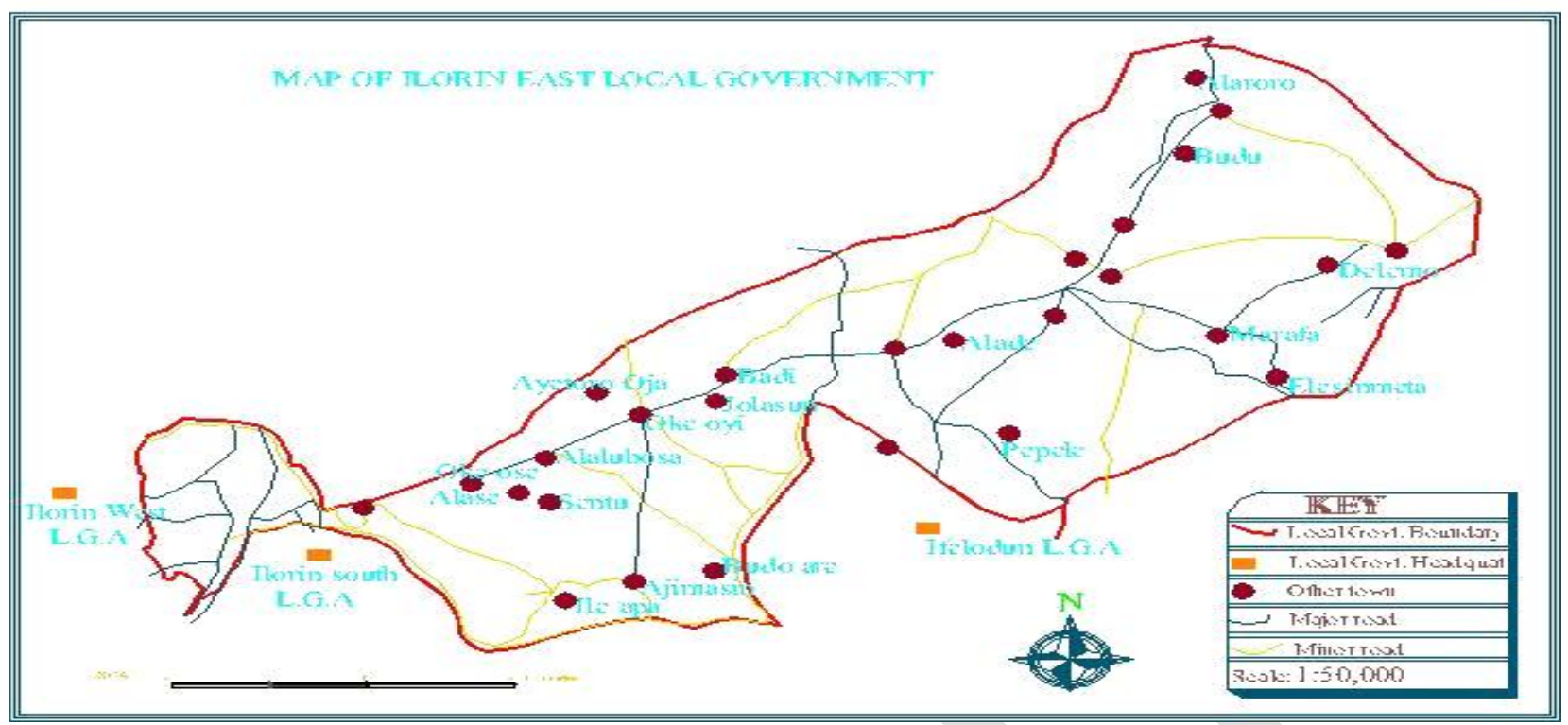

Figure 2: Map of Ilorin East Local Government (source: adapted from Atlas, 2017)

\section{Findings and Discussion}

The thrust of this study is in the understanding of the level of facility adequacy, level of community development and the probable relationships between them. This section is thus organized into three: public facilities appraisal, Level of development appraisal andrelationship between public facilities and community development.

\section{Facility Appraisal}

The list of basic facility varies from place to place in different part of the world. Therefore, the list will always look imperfect from time to time. For this study, the public facilities specifically considered and measured within the wards necessarily includes: tertiary hospital, maternity, dispensary, shopping Centre, traditional market, Postal agency, public toilet, primary school, secondary school, community borehole, police station, government institution, refuse disposal, electricity, drainage, roads, library, sewage, sewerage, bank, town hall and street furniture. Internal, external as well as service qualities where applicable are scaled on the questionnaire for ordinal rating.

The table which is a surrogate for facility provision appraisal is a summative composite data which combines through the likert scaling method; availability, population-facility ratio, physical spatial and economic accessibility, efficiency (measured by the rate of breakdown/maintenance) and the user's satisfaction.Each of the listed facilities were alsoajudged based on their functionality, space standard, 
service radii, adjoining environment, stress such as man-hour loss and other costs, the quality of service such as potable quality of water frequency of service and residents satisfaction among others.

\section{Table 1: Public Facilities Appraisal}

\begin{tabular}{|c|c|c|c|c|c|c|c|c|c|c|c|c|}
\hline \multirow[t]{2}{*}{ FACILITY } & \multicolumn{12}{|c|}{ WARDS } \\
\hline & 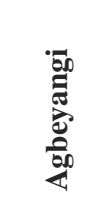 & $\frac{0}{\frac{\pi}{2}}$ & 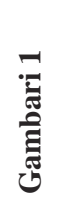 & 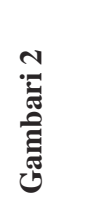 & 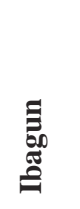 & 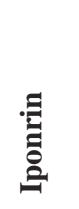 & 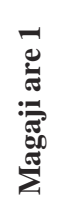 & 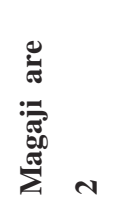 & 苞 & $\sum_{i}^{\mathbb{\pi}}$ & 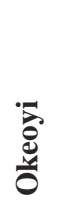 & 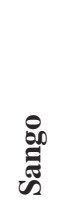 \\
\hline State hospital & 26 & 27 & 37 & 51 & 26 & 22 & 23 & 23 & 33 & 33 & 93 & 69 \\
\hline Maternity & 22 & 20 & 11 & 128 & 35 & 24 & 64 & 68 & 27 & 34 & 93 & 91 \\
\hline Dispensary & 33 & 38 & 90 & 164 & 48 & 39 & 90 & 75 & 42 & 43 & 124 & 184 \\
\hline Shopping centre & 0 & 0 & 0 & 0 & 0 & 0 & 0 & 0 & 0 & 0 & 0 & 0 \\
\hline Traditional mrk & 33 & 32 & 95 & 133 & 56 & 48 & 79 & 46 & 22 & 22 & 83 & 110 \\
\hline Postal Agency & 0 & 0 & 0 & 0 & 0 & 0 & 0 & 64 & 0 & 0 & 0 & 0 \\
\hline Public toilet & 0 & 0 & 0 & 0 & 0 & 0 & 0 & 0 & 0 & 0 & 0 & 0 \\
\hline Primary school & 29 & 9 & 8 & 134 & 82 & 51 & 23 & 70 & 29 & 29 & 19 & 100 \\
\hline Sec school & 29 & 32 & 44 & 126 & 80 & 42 & 39 & 66 & 29 & 29 & 98 & 145 \\
\hline Com. Borehole & 33 & 47 & 77 & 144 & 86 & 63 & 56 & 74 & 44 & 29 & 104 & 164 \\
\hline Police Station & 19 & 10 & 57 & 58 & 10 & 20 & 46 & 60 & 26 & 16 & 42 & 72 \\
\hline Govt institution & 0 & 0 & 0 & 0 & 0 & 0 & 0 & 0 & 15 & 18 & 93 & 26 \\
\hline Refuse disposal & 26 & 24 & 49 & 82 & 46 & 31 & 45 & 46 & 21 & 22 & 64 & 91 \\
\hline Electricity & 0 & 0 & 0 & 0 & 0 & 0 & 0 & 0 & 0 & 0 & 0 & 0 \\
\hline Drainage & 3 & 11 & 32 & 99 & 0 & 10 & 20 & 53 & 21 & 27 & 88 & 129 \\
\hline Roads & 12 & 16 & 67 & 81 & 26 & 22 & 36 & 63 & 12 & 14 & 34 & 52 \\
\hline Library & 0 & 0 & 0 & 0 & 0 & 0 & 0 & 69 & 0 & 0 & 0 & 0 \\
\hline Sewage & 44 & 45 & 28 & 5 & 15 & 21 & 36 & 69 & 60 & 6 & 12 & 69 \\
\hline Sewerage & 34 & 51 & 21 & 15 & 33 & 21 & 27 & 69 & 60 & 6 & 21 & 69 \\
\hline Bank & 0 & 0 & 0 & 0 & 0 & 0 & 0 & 72 & 0 & 0 & 0 & 62 \\
\hline Town hall & 7 & 9 & 25 & 5 & 23 & 13 & 23 & 0 & 6 & 10 & 31 & 46 \\
\hline Street furniture & 0 & 0 & 0 & 46 & 0 & 0 & 71 & 11 & 0 & 0 & 0 & 0 \\
\hline Total & 350 & 371 & 641 & 1261 & 566 & 427 & 678 & 998 & 447 & 338 & 999 & 1479 \\
\hline Mean & 24.1 & 16.9 & 29.1 & 57.3 & 25.7 & 19.4 & 30.8 & 45.4 & 20.3 & 15.4 & 45.4 & 67.2 \\
\hline
\end{tabular}

Source: Author's field survey (2017)

There was a marked inadequacy in the provision or organization of shopping centers, postal agencies, public toilet, governmental institutions (Government's presence), electricity and street furniture. As expected banking halls are center seeking land uses and are therefore place specific.In all, Sango ward 
was observed to have the relative highest performance in terms of facility provision (1479). The ward is followed by Gambari ward 2 scoring 1261.Okeoyi (999), Magaji Are ward 2 (998), Magaji Are ward 1(678), Gambari ward 1 (641), Ibagun (566), Marafa (447), Iponrin (427), Apado (371), Agbeyangi (350) and Maya (338) wards followed in relative importance of facility adequacy in Ilorin East. This generally low level of facility provision may implicate socio-economic development and other livability issues in the area. This necessitates a development appraisal.

\section{Development Appraisal}

This section examines the level of development. Again, the analysis here made use of summative composite variables to explain the level of development among the sampled wards. The variables include: education, sanitation, health, relative affluence, quality of housing, property value (trading, patronage of trade, increase in transport, increase in land price, employment, income), GDP, Per capita income, traffic flow, liveability, relative absence of crime, legibility, incidence of landscape development, level of industrialization, liveability, incidence of in-migration, new buildings, relative disappearance of abandoned property, living standard,imageability, and new investments.

\section{Table 2: Development Appraisal}

\begin{tabular}{|c|c|c|c|c|c|c|c|c|c|c|c|c|}
\hline \multirow[t]{2}{*}{ FACILITY } & \multicolumn{12}{|c|}{ WARDS } \\
\hline & 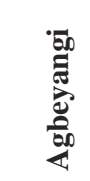 & $\begin{array}{l}\frac{0}{0} \\
\frac{2}{2}\end{array}$ & 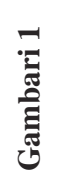 & 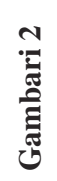 & 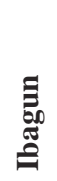 & 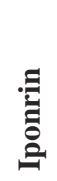 & 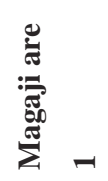 & 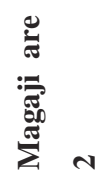 & 丞 & $\sum_{i}^{\pi}$ & 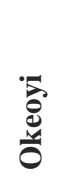 & 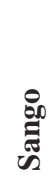 \\
\hline Education & 47 & 45 & 45 & 51 & 46 & 32 & 43 & 44 & 58 & 57 & 58 & 36 \\
\hline Sanitation & 34 & 42 & 34 & 34 & 32 & 37 & 39 & 33 & 41 & 36 & 43 & 41 \\
\hline Health & 36 & 35 & 49 & 47 & 37 & 41 & 44 & 39 & 37 & 39 & 39 & 48 \\
\hline Rel. Affluence & 34 & 33 & 57 & 47 & 46 & 35 & 39 & 52 & 38 & 41 & 47 & 47 \\
\hline Housing Quality & 32 & 31 & 42 & 51 & 51 & 39 & 47 & 51 & 36 & 44 & 42 & 53 \\
\hline Property value & 33 & 49 & 43 & 51 & 41 & 43 & 49 & 47 & 35 & 41 & 51 & 42 \\
\hline GDP & 31 & 34 & 49 & 52 & 51 & 42 & 47 & 47 & 39 & 32 & 49 & 43 \\
\hline /capita income & 37 & 33 & 43 & 47 & 51 & 41 & 47 & 51 & 36 & 49 & 47 & 53 \\
\hline Traffic flow & 57 & 49 & 49 & 57 & 59 & 55 & 56 & 51 & 49 & 52 & 49 & 43 \\
\hline Rel Crime & 49 & 52 & 52 & 51 & 51 & 48 & 57 & 61 & 56 & 59 & 55 & 53 \\
\hline Legibility & 41 & 43 & 32 & 49 & 31 & 34 & 33 & 36 & 39 & 34 & 34 & 59 \\
\hline Rel Landscape & 48 & 39 & 37 & 47 & 48 & 49 & 39 & 44 & 44 & 36 & 47 & 44 \\
\hline Industrialization & 47 & 47 & 46 & 43 & 39 & 57 & 52 & 51 & 39 & 34 & 47 & 67 \\
\hline Livability & 53 & 42 & 51 & 43 & 41 & 42 & 51 & 49 & 47 & 32 & 51 & 57 \\
\hline In-migration & 42 & 51 & 41 & 53 & 49 & 43 & 47 & 42 & 49 & 33 & 51 & 51 \\
\hline
\end{tabular}




\begin{tabular}{|c|c|c|c|c|c|c|c|c|c|c|c|c|}
\hline New buildings & 43 & 49 & 51 & 53 & 51 & 49 & 47 & 39 & 47 & 31 & 52 & 74 \\
\hline Abandonment & 53 & 47 & 51 & 53 & 48 & 43 & 51 & 49 & 47 & 37 & 47 & 49 \\
\hline Living standard & 43 & 49 & 59 & 58 & 51 & 49 & 51 & 53 & 56 & 57 & 57 & 83 \\
\hline Imageability & 53 & 55 & 51 & 53 & 52 & 52 & 61 & 59 & 57 & 49 & 51 & 68 \\
\hline Newinvestment & 58 & 49 & 57 & 57 & 58 & 44 & 49 & 54 & 47 & 41 & 47 & 64 \\
\hline Mean & 43.6 & 43.7 & 46.5 & 49.9 & 46.2 & 43.8 & 47.5 & 47.6 & 44.9 & 41.7 & 48.3 & 53.8 \\
\hline
\end{tabular}

Source: Author's field survey (2017)

It is important to state at this outset that there was observed a generally poor level of development in the study. Testing with Chi-square at alpha of .005 indicated that there is no significant difference when all the 12 wards were compared. However, Sango was observed to be relatively more developed above other wards with an aggregate score of 53.8. This is followed by Gambari 2 (49.9), OkeOyi (48.3), Magaji Are 2 (47.6), Magaji Are 1 (47.5), Gambari 1 (46.5), Ibagun (46.2), Marafa (44.9), Iponrin (43.8), Apado (43.7), Agbeyangi (43.6) and Maya (41.7). A cursory observation of the pattern of the level of development observed among the wards exudes some similarities with the one for facility appraisal. In other words, wards with low level of facility provision seem to have a correspondingly low level of development except in a few cases. This raises an hypothesis that there can be a concomitant relationship between public facility adequacy and community development. The next section tests this hypothesis using the linear regression analysis.

\section{Relationship between Facilities and Physical Development}

A very high and reliable relationship was found between public facility provision and community development. With the correlation coefficient of .949 and coefficient of determination of .900 it was observed that about $90 \%$ of development in the communities studied depended on the adequacy of the public facility provided. In other words, there scarcely can be development without adequate provision of public facilities. The F value of 89.893 and the probability value of .000 signify that the assertion on the relationship is with $99 \%$ confidence level

Table 5: Relationship between RLI and BDI

\begin{tabular}{|l|l|l|c|l|l|l|l|}
\hline Dependent & Independent & $\mathrm{R}$ & $\mathrm{R}^{2}$ & $\mathrm{~F}$ & P.Value & $\mathrm{B}$ & PValue \\
\hline Development & Facility Adequacy & .949 & .900 & 89.893 & .000 & Constant : 40.331 & .000 \\
& & & & & & Facility : .186 & .000 \\
\hline
\end{tabular}

Source: Authors' Computation 2017 
Calibrating the model with community development as the dependent variable and facility provision as the independent therefore:

$\mathrm{Y}=\mathrm{a}+\mathrm{bx}$

Community development $=40.331+186$ (Public facility)

This implies that a unit increase in the provision of public facility would produce a corresponding .186 increase in community development; and the more the increase in the facility production in terms of quantity and quality the higher will be the fold of increase in community development. If development is desired in any community, focus should be on the provision of public utility and facilities. The presence of facilities in an area has the propensity to draw more population into the area, thereby, enhancing the required population threshold for socio-economic improvement. Availability of adequate facility spurs residents into creative activities that may move them up the socio-economic ladder. Man-hour loss, stress and poor healthmay be salvaged in an area with good public facilities. Facility development is therefore a sine-qua-non for sustainable community development.

\section{Recommendation and Conclusion}

The study has been able to investigate the level of public facility adequacy as well as the level of development in Ilorin East Local government area. Adequacy in the provision of public facility and community developmentwerefound to be concomitant. And provision of public facilities are prerequisite to community development..For example,good road will enhance transportation activities which will increase the incidences of migration to the community also increase the level of trade and at the same time the income level. The poor level of facility development in the area was found to be causal to the poor level of development in the area. The abysmal provision of public facility in Ilorin East local Government therefore calls for urgent attention, if environmental retrogression would be forestalled. It is therefore suggested that basic functional facilities provision should be ensured in each neighborhood and wards.

Based on the residents' perceived inadequacies in the public facilities in their area, coupled with their willingness to cooperate together to ensuring provision of such facilities, public-private partnership may be introduced where the community development associations (CDAs) would be encouraged to initiate a publicfacility projects from the residents contributions and assistance be given by the Government and vice versa. While legal, technical and financial supports are necessarily important from the municipal Government, sustainability in facility provision as well as general development in the area also require the involvement of the community members as co-stakeholders in the maintenance of the provided facilities. This will hereby enhance the growth, development and the standard of living in the environment. 


\section{References}

Adeboyejo and Abolade (2007): The pattern, Direction and factors responsible for urban growth in a developing Africa city: A case study ogbomoso

Akinbamijo, O.B. (2006). Predicting urban health status- An Empirical modelling Approach from cities in southwest Nigeria. The social science I (2), 133-138

Akinbamijo, O.B. \&Fasakin, J.O., (2006). Spatial Disparities in residential Housing Health- An Application of model Akure, southwest Nigeria. The social science I (2), 158-163

Esfahani, H.S (2005), "Measuring Public Sector Performance in infrastructure," In shah, A (Ed.), public service Delivery, World Bank; Washington Dc.

Essien, A, Elizabeth, E., \&Akintoye, O.A. (2012). Urban Poverty and Environmental Degradation in calabar Area of Cross River state, Nigeria. Global journal of human social science, l2(6), 49-56

Fakere, Alexander A, Ayeni Dorcas A., (2013). Communal Facilities and Residential Neighborhood in Akure, Nigeria.Civil and Environmental Research. ISSN 2222-1719(Paper) ISSN 22222863(Online) Vol 3, No1, 201

Garfeild and Lovejoy (1964), Public Utility EconomicsISSN 13.97801373936711,ISSN 10.137393679 Hirschman (1958). The strategy of Economic Development. New Haven, Conn.: Yala University ISBN 0300-00559-8

Ibrahim D.O and Y.G. Musa Haddary. 2010. Concept of value for public infrastructure Development. "Presentation at the Nigerian institute of Quantity Surveyors 3-Day International workshop on public private partnership approach to infrastructure Development in Nigeria Abuja".

Igbozurike, (1998).Ecological balance in Tropical Agriculture. Vol. 61, No 4, pp.519-529

Losch. A. (1954) A model of central place. Republished by Oxford university press (2009)ISSN 13:9780199231805 
McNeil M. (1993); 'The Changing Nature of Infrastructure'.The urban Age Vol 1 No 2.

ObateruOluremi I (2003) Land Subdivision Basics. Ibadan: Penthouse Publications.

Obateru (1993) "Land Subdivision Basics" Pent house Publishers. Nigeria

Okuneye, P.I. et al (1990): "Rural Development Strategy in Nigeria, Past Experience and

Some Lessons".Journal of Rural Cooperation.Vol. XVII; Pp 32.

Olotuah, A.O., \&Adesii, O.S. (2005).Housing Poverty, Slum formation and Deviant Behavior.Paper presented at the Housing studies Association, University of Lincoln, U k, 8-9 September, 2005.

Owoeye, S.O. (2012). Built Environment Decay and Health Situation of Slum Dwellers in Residential cores of Akure.America Journal of Human Ecology, l 2(6), 33-39

Ugwu I. C (1993); 'Consideration for Financial Urban Infrastructural Development'. Proceedings of the $25^{\text {th }}$ NITP Conference.

Smith Shuck (2000) Future Directions in Rural Development

World Bank (1994). Infrastructural for Development, World Development Report 1994.

New York: Oxford University press 